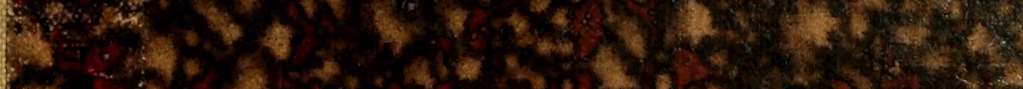

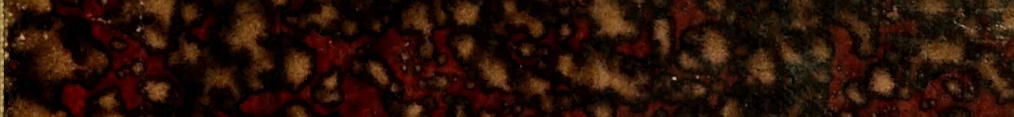

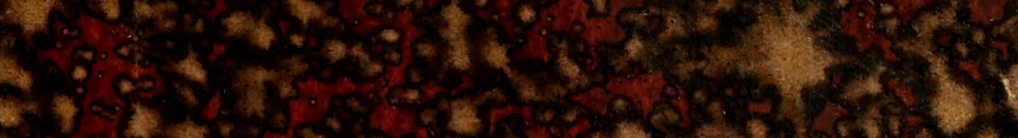

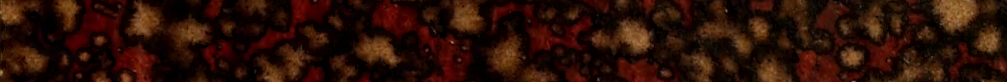

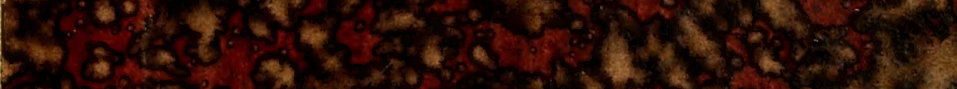

25. ${ }^{3}$.

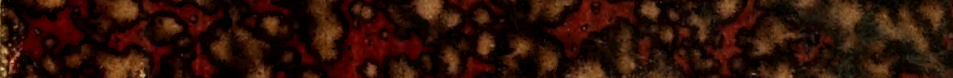

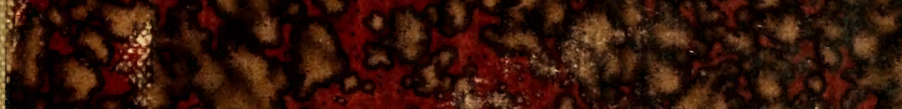

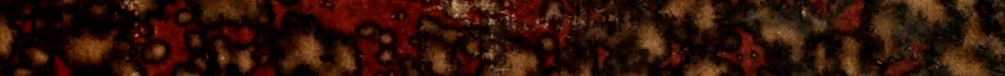

7 is

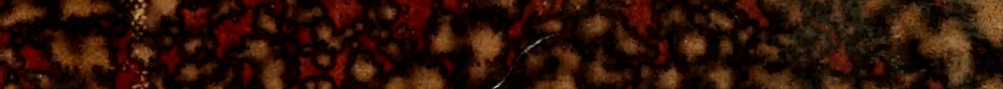

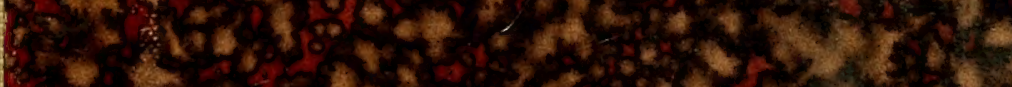

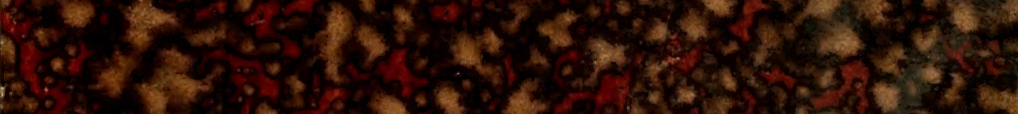

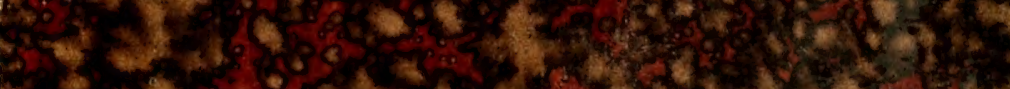

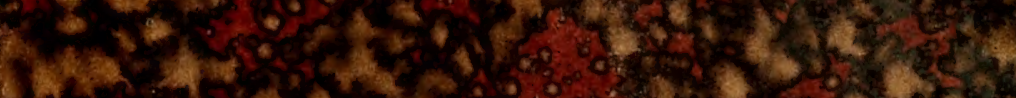

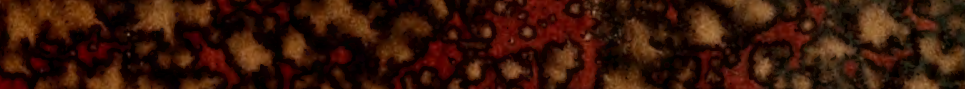

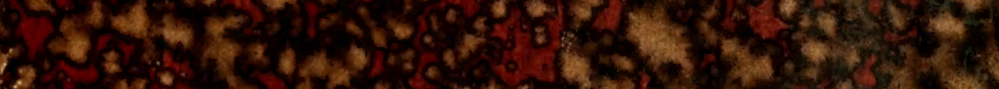

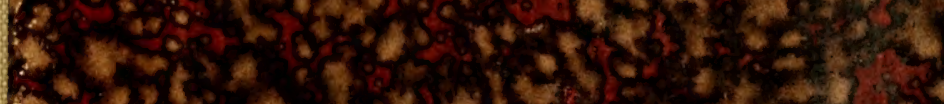

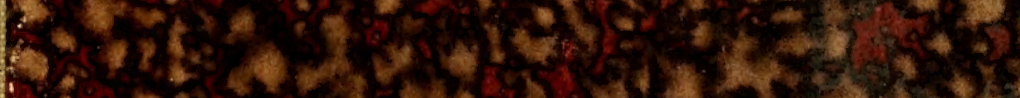

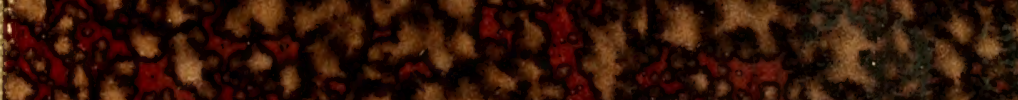

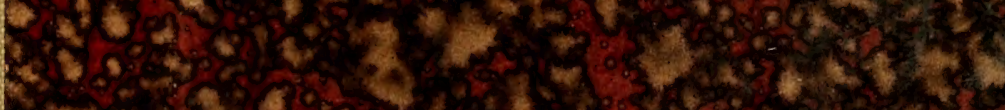

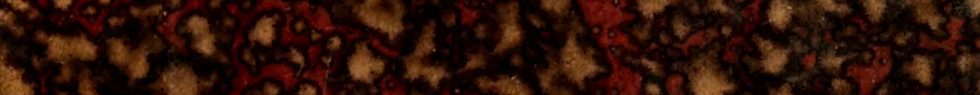

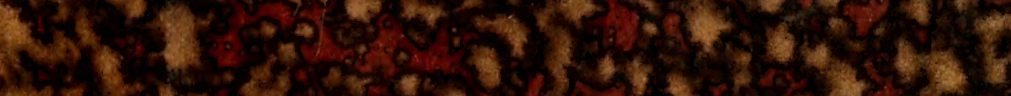

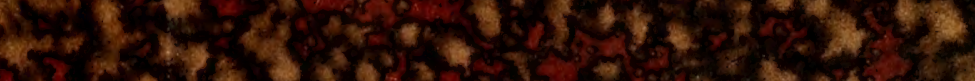
a

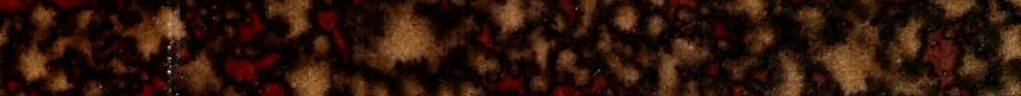

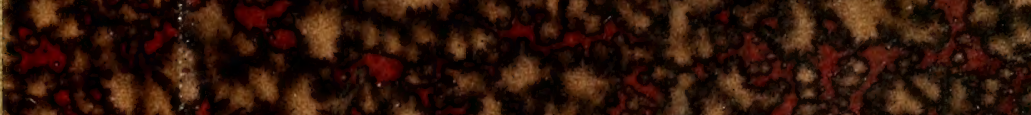

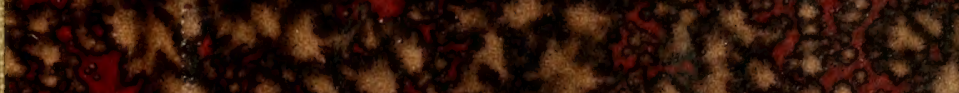

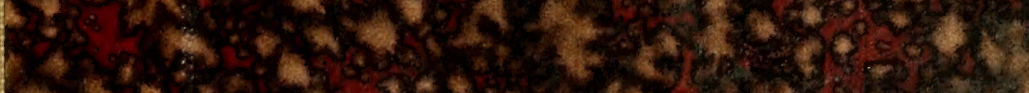

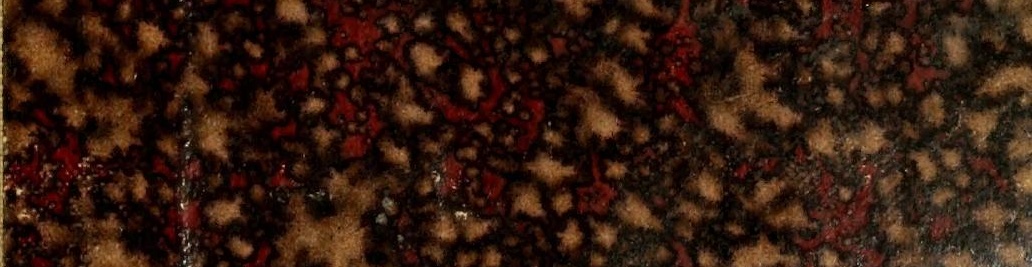


HARVARD UNIVERSITY.

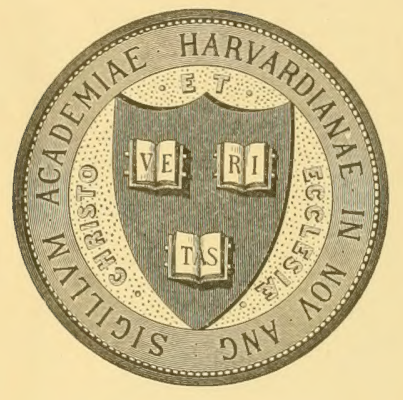

LIBRARY

OF THE

MUSEUM OF COMPARATIVE ZOÖLOGY.

18.444

Library of Alpheus tlayatt

October 28, 1902 


\section{PRESENT CONDITION}

OF THE

\section{EASTERI OYSTER EXPERIVENT}

AND THE

NATIVE OYSTER INDUSTRI.

REPORT

oF

\section{THE STATE BIOLOGIST}

JUXE $30,1900$.

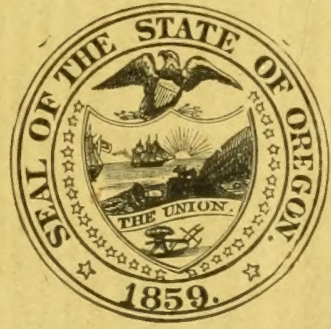

SALEM, OREGON

W. I. LEEDS, STATE PRINTER 



\title{
PRESENT CONDITION
}

OF THE

\section{EASTERI OYSTER EXPERIMENT}

\author{
AND THE
}

\section{NATIVE OYSTER INDUSTRY.}

\author{
REPORT
}

$O F$

\section{THE STATE BIOLOGIST}

\author{
JUNE $30,1900$.
}

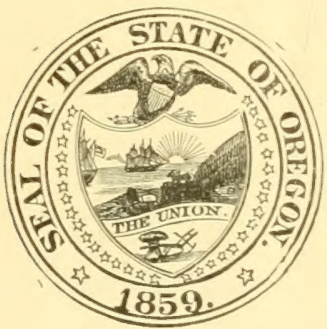

SALEM, OREGON

IV. II. LEEDS, STATE PRINTER 1900 



\title{
PRESENT CONDITION
}

OF THE

\section{EASTERN OYSTER EXPERIMENT.}

\author{
Biological Laboratory, \\ UNIVERSity OF Oregon, \\ Eugene, January 30, 1900.)
}

His Excellency, T. T. Geer, Salem, Oregon:

I take pleasure in presenting to you herewith a report on the status of the Eastern Oyster experiment, conditions of the native oyster industry, etc., and include several tables of densities and water temperatures taken within the last three years, and mailed to Washington, D. C., but not hitherto published here.

I should like to emphasize at the very beginning of the report a few points which I regard as important, viz. :

1. I have beeen very careful in this work to state to the public as facts only what we have actually found to be true, and have been extremely conservative in statements which might lead our citizens to expect immediate results.

2. We know that the introduced oyster flourishes, grows with extreme rapidity, and soon becomes an excellent marketable product.

3. We know that they spawn here.

4. We have found a few young oysters undoubtedly hatched in Yaquina Bay.

Public opinion appears to have decided, with questionable propriety, that, as far as successful propagation is concerned, the experiment is a failure, and many of the oystermen of Yaquina Bay, being intensely practical and not at all scientific, share this view. Similar work on the Atlantic Coast (I refer to the experiments of John A. Ryder, see Report of Commissioner of Fish and Fisheries for 1885), demonstrating that oyster spat can be obtained in enormous amounts by resorting to pond culture, prove that we have no right to draw hasty conclusions as regards our work here. 
I have no hesitation in saying, that, even should we be unsuccessful in propagating the introduced species here, there is profit, much profit, for an individual, or a company, provided ground could be secured for such purpose, in importing seed oysters from the east, planting them in our bays (they will grow in almost any of our bays), and selling to home trade a year or two years or more later. As is well known, an immense business of this kind is conducted at San Francisco. Now, then, if pond culture of embryo oysters can be resorted to here (I have already alluded to a successful instance of its use in the east), how much more profit would there be in raising seed here than in purchasing it on the Atlantic Coast and paying freight rates to the Pacific.

While I confidently believe that, in time, oystermen will find more or less eastern oysters in Yaquina Bay, which have had their origin, naturally, in the plant introduced by the United States Fish Commission, it may take many years before this result is attained, and my chief, in fact, my only reliance for immediate results, now rests upon pond culture in connection with artificial fertilization. Artificial fertilization consists in mixing the ripe generative products from both sexes of oyster in receptacles filled with salt water, and when the developing eggs have reached the swimming stage of the embryo, or later, turning them into the bay, or better, into ponds where proper temperature and saltness can be maintained until they fix themselves as "spat," this spat to be later deposited in the bay.

With this idea of pond culture in mind, a cement pond was made last summer in the tide land with the expectation of testing its efficiency next summer.

Of all the bays of the Oregon Coast examined during the last three years, Yaquina Bay, though not an ideal place, appears most suited for successful propagation of this delicious bivalve, although an abundance of oyster food was found everywhere, and, as stated above, this oyster will undoubtedly grow finely in almost any bay on our coast.

I here insert, seriatim, and very briefly, the conditions found by the writer to prevail in the localities studied, together with a few tables of salinity and temperatures. The density of ocean water is 1.025 . 
REPORT OF STATE BIOLOGIST.
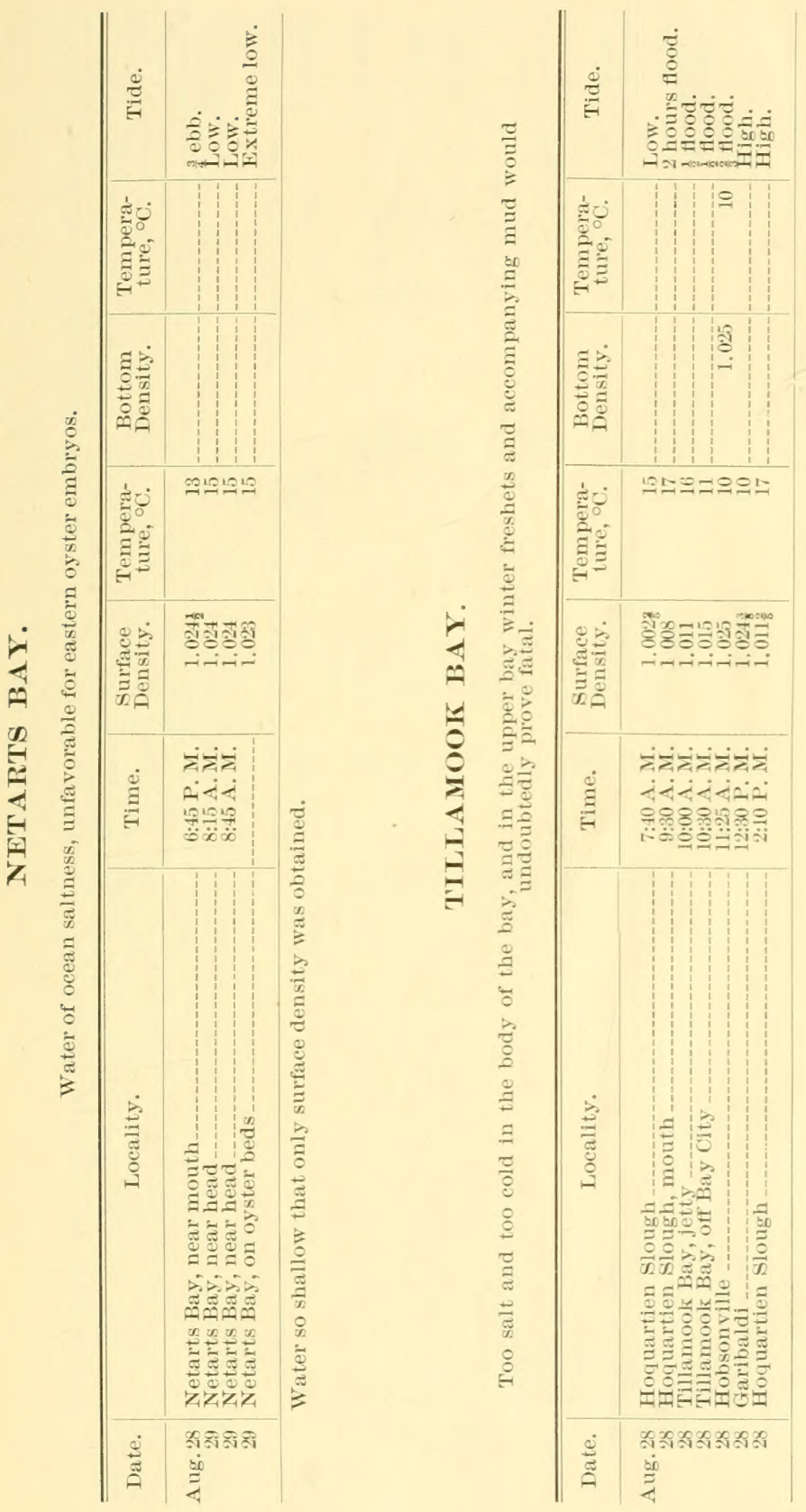
REPORT OF STATE BIOLOGIST.

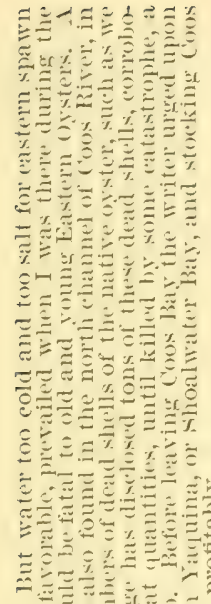

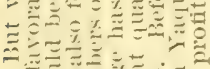

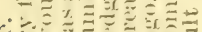
$\frac{2}{2}= \pm \equiv$

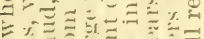

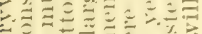

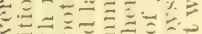

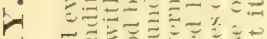
4 a A

20

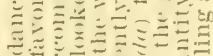

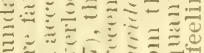

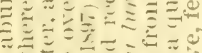
$\because=\Xi \pm \equiv$

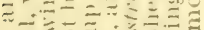

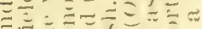
₹

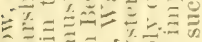

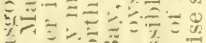

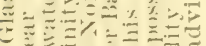

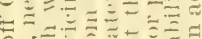

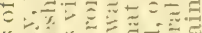

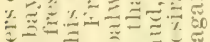

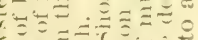

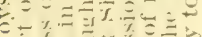
更

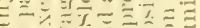
等=

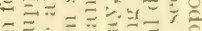
引

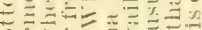
政:

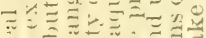
$\Xi \Xi: \exists r \equiv \Xi$ $\Xi 三$

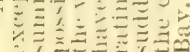

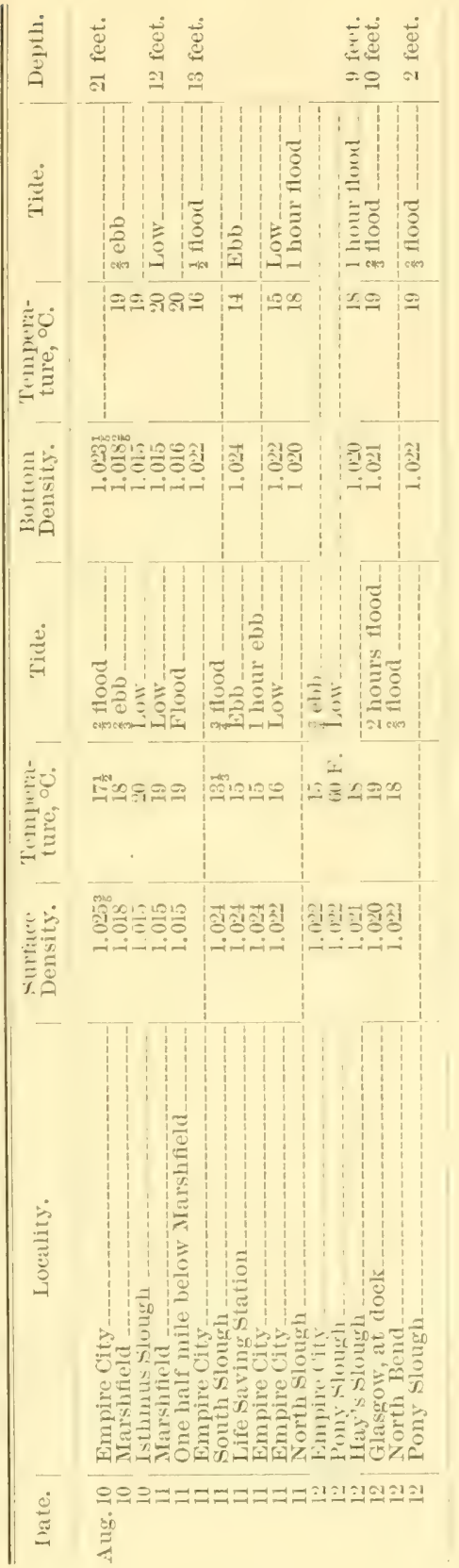




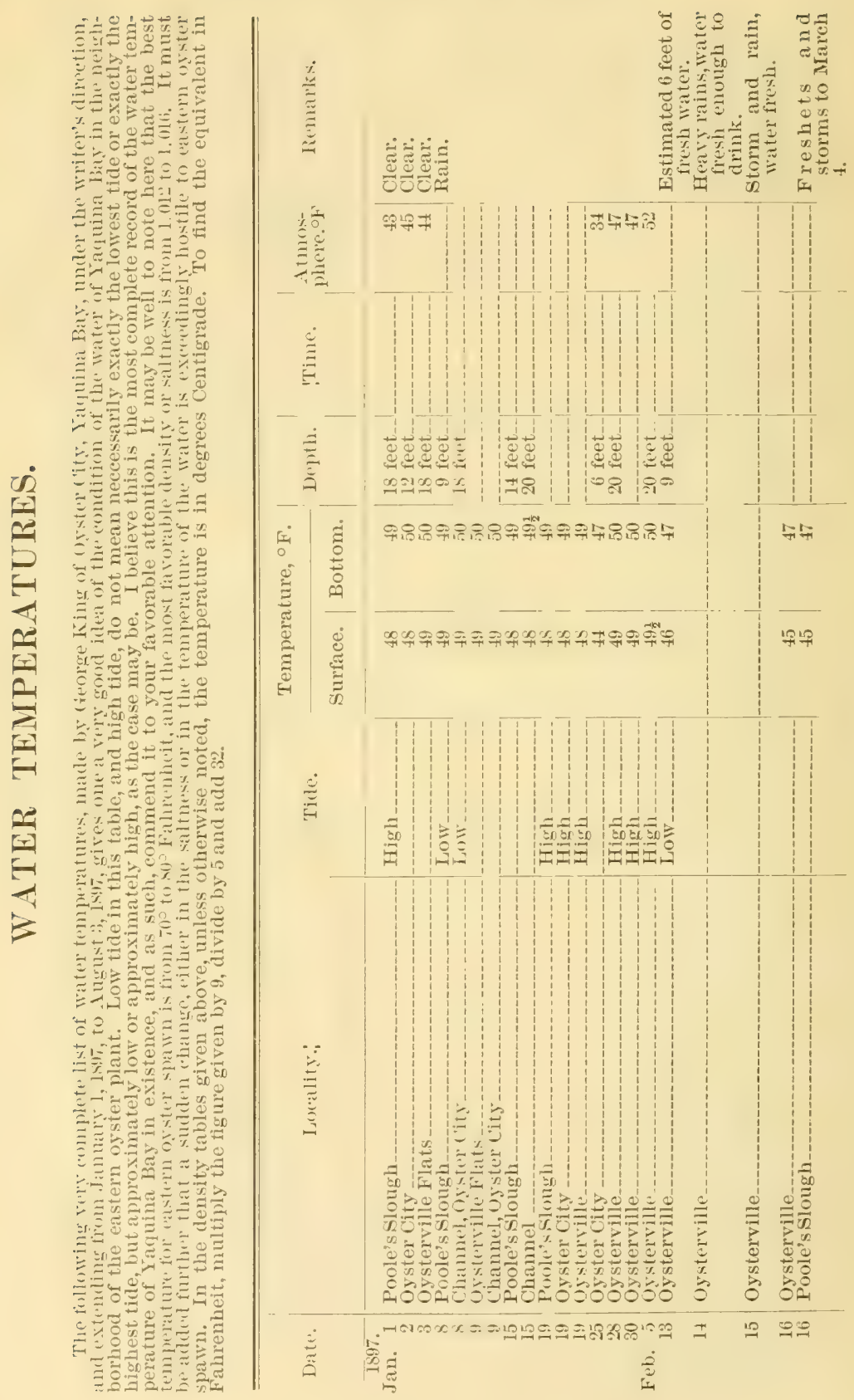




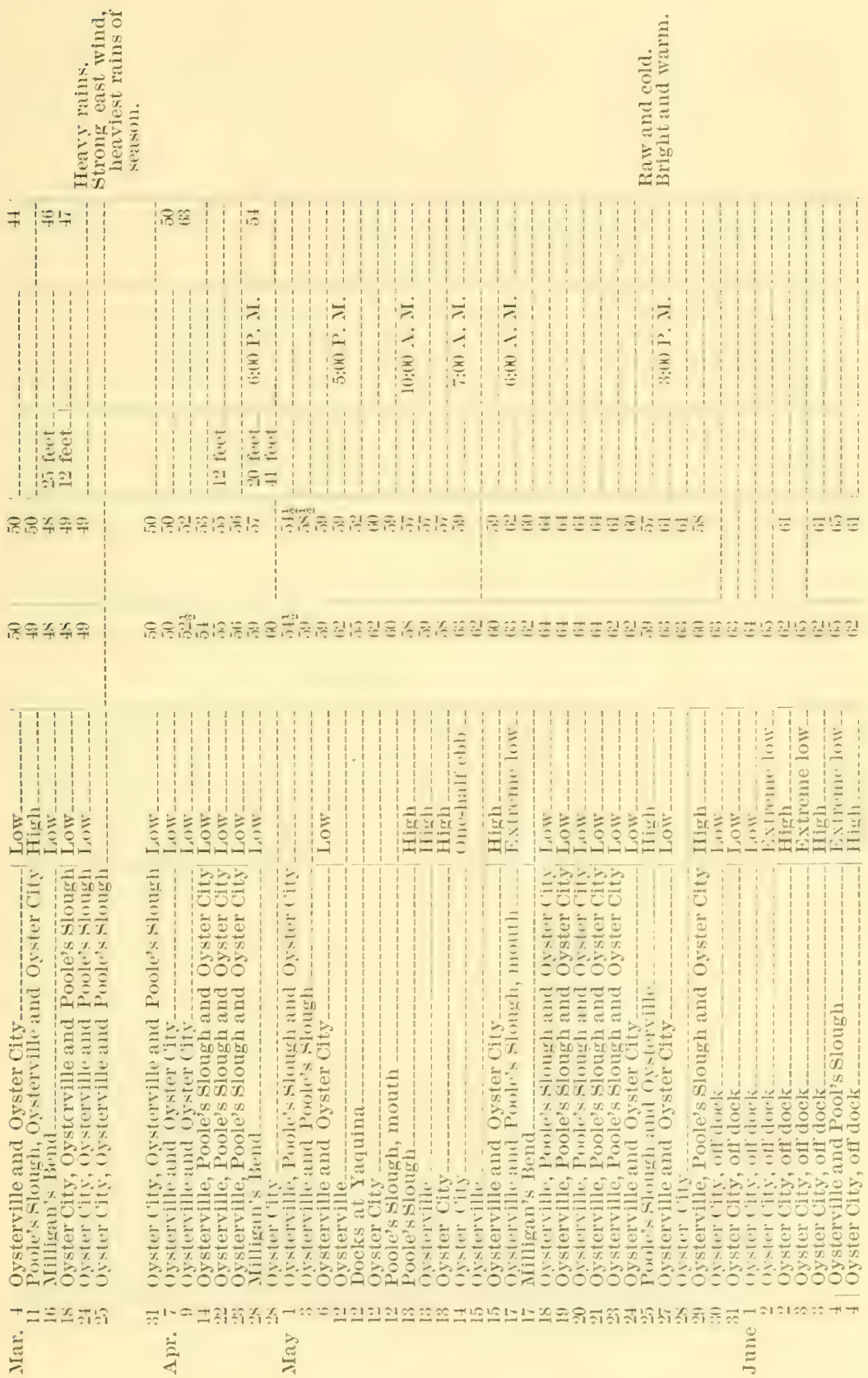




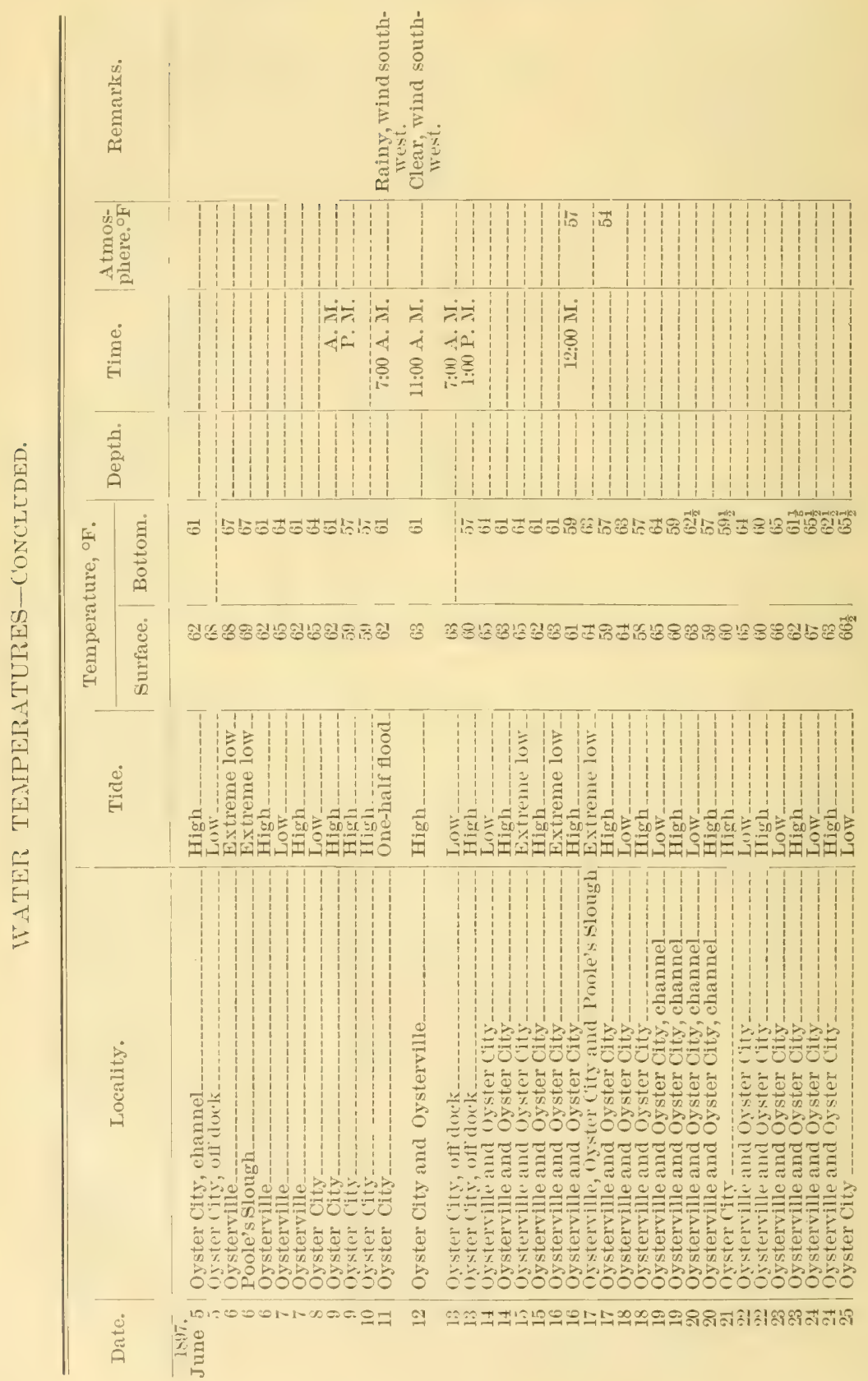




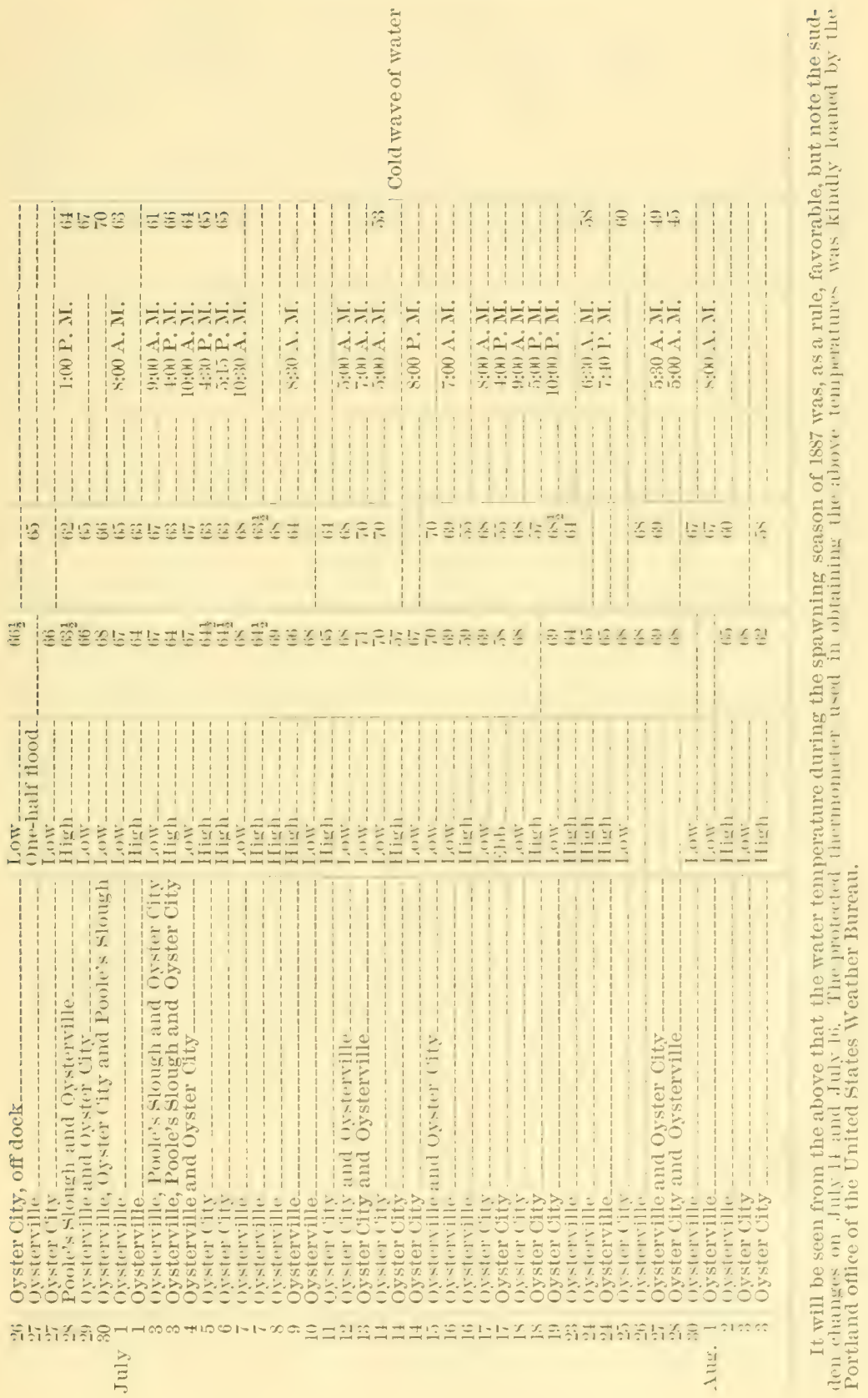




\section{SECOND CONSIGNMEN'T' OF EASTERN OYSTERS.}

Since the first consignment in 1896, the United States Fish Commissioner, George M. Bowers, has been liberal enough to present the state with ten barrels more of the variety known as Princess Bays, making in all thirty-two barrels of eastern oysters donated the state and planted in Yaquina Bay. Through the courtesy of President John J. Valentine, of the Wells, Fargo Company, this second consignment was brought from New Yrork to Yaquina free of charge. The United States Govermment bore the expense of tramsporting the first consignment.

A telegram from Auburn, California, received at Eugene, October 30, advised the writer that the oyster's would pass Sacramento that night, bringing them into Albany on the morning of November 1, where they were met and arrangements made with the courteous officials of the Corvallis and Eastern Railroad to have them unloaded at Oysterville. They were planted the next morning, some with the former plant, and some farther up the bay in deep water. This consignment left New York City on October 25; they were, therefore, just eight days en route. Not a single dead oyster was found in the entire lot. The consignment weighed in the vicinity of two thousand five hundred pounds.

The small sum $(\$ 300)$ appropriated by our last legislature for this work having been nearly exhausted, the United States Fish Commissioner, George M. Bowers, has practically consented to honor bills representing the expenses of next summer's work. This generosity on the part of the fish commissioner is highly appreciated, for, otherwise, the work would be at a standstill during the coming summer, at which time it is now intended to make a thorough trial of the concrete pond constructed last season.

\section{CONDITIONS OF 'THE NATIVE OYSTER INDUSTRY.}

Ialuina Bay oystermen get at present $\$ 2.50$ to $\$ 2.75$ per sack for native oysters, a San Francisco firm having contricted with most of the oystermen for this season's output at the latter figure. The oysters on the native beds are so closely worked now that one-half a sack on a tide is consid- 
ered fair work, though one sack is sometimes obtained. In the past, the business has heen much more profitable thin at present. The oysters have dwindled in numbers and in size. owing to a too persistent tonging, together with a lack of foresight on the part of the oystermen. If they could unite in a determination to forbid all tonging for two years or more on certain reserved portions of the natural bedis, and persist for a number of years in such a plan, using care with the unmarketable seed, besiles taking the hest possible precautions along modern lines for catching "spat," I believe the industry could be restored to something like what it was ten years ago. But if the present methods continue, I will predict the extinction of the industry hefore many ratr.s. There are at present less than twelre men oystering at Yaquina Bay, yet if all of that small number depended for the ir living on selling oysters, they would fare badly. Some of them turn their attention to salmon fishing cluring a part of August, September, October and Norember. The oystermen who do not fish claim, and some of those who do fish acknowledger that while drifting at low tide the weighted nets

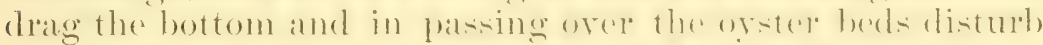
the oysters at a time when the oyster spat is still young, delicate and easily injured, besides rolling the adult oysters about at a time when they should be let alone, namely, the spawning period. From nexestatily limited observations on my own part and from careful inquiry from reliable parties, I am inclined to think that this complaint is well founded.

The oystermen have been in the past united in the Yaquina

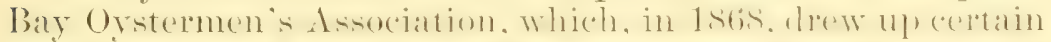
laws regulating orstering, which laws were alterwatrds made state laws by the legislature. In accordance with these laws, one is obliged to have resided twelye months in the state and six months in the county before he can tong oysters. Each oysterman can obtain from the state for use as private bed two acres of tide land, and only two.

Respectfully,

$$
\begin{aligned}
& \text { F. L. WASHBURN. } \\
& \text { State Biologist. }
\end{aligned}
$$









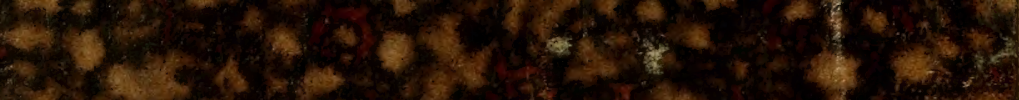

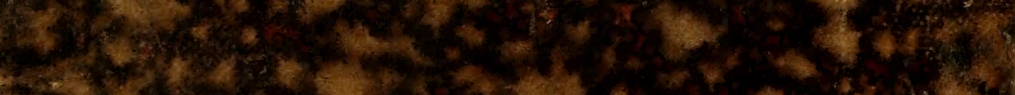

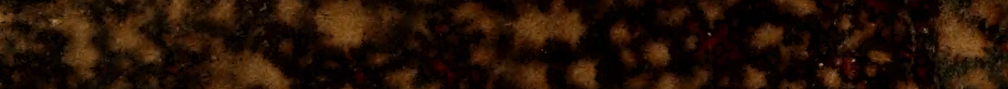

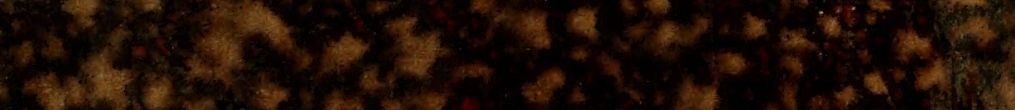

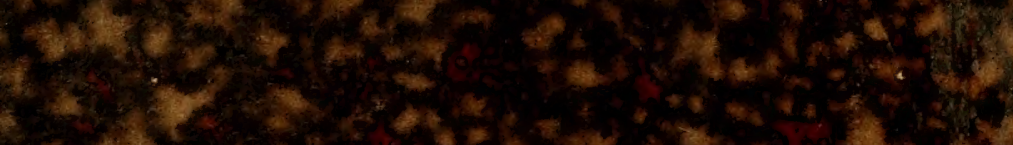

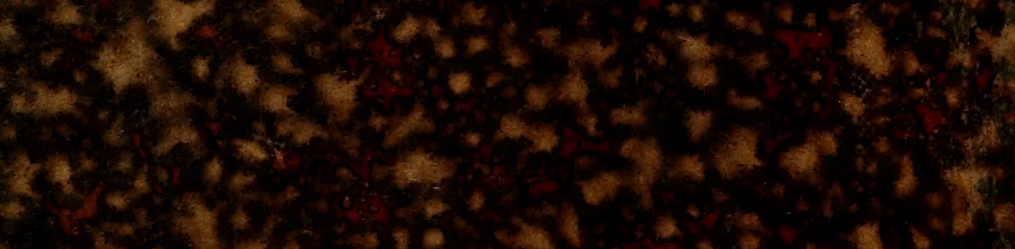

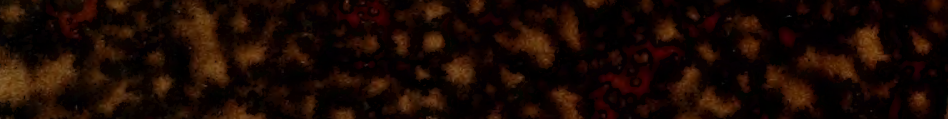

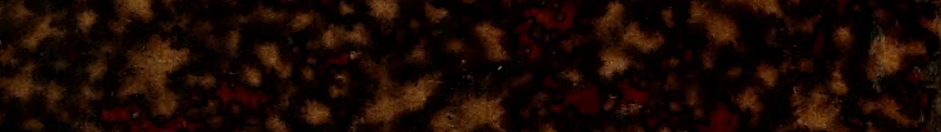
$4 \times 3 x+4: 20$

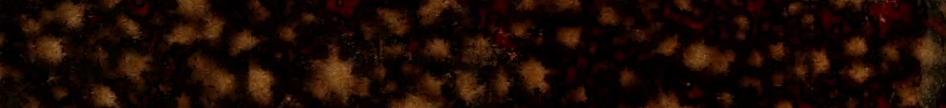
(3)

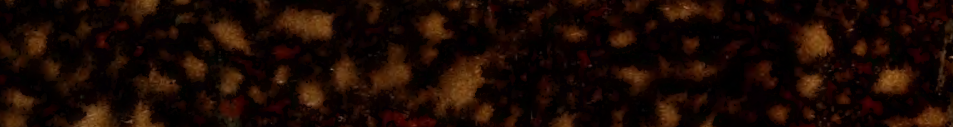

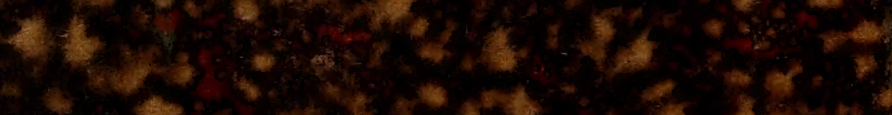

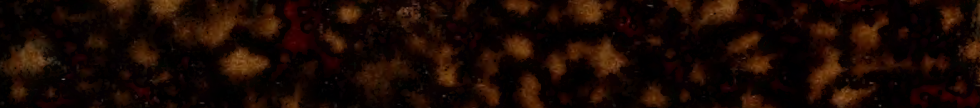

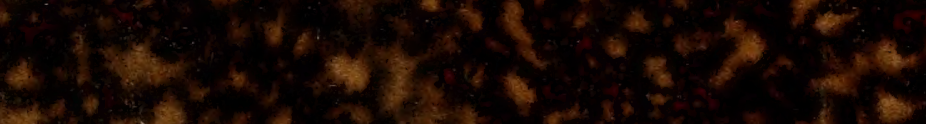

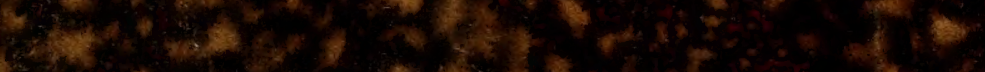

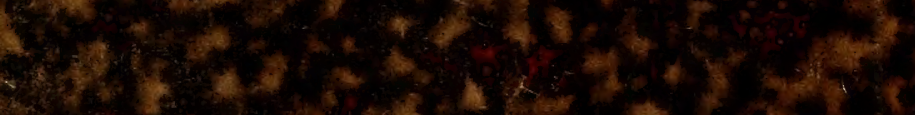
$x^{2}-2,4, x \cdot x, x+3$

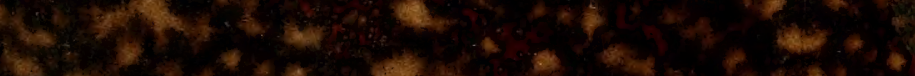

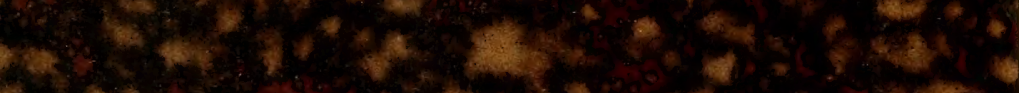

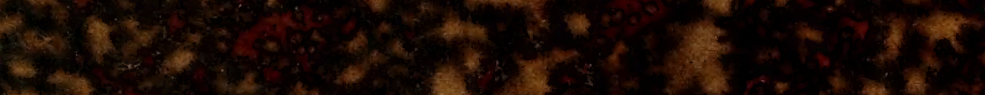

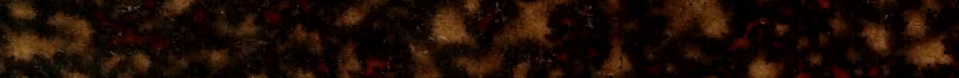

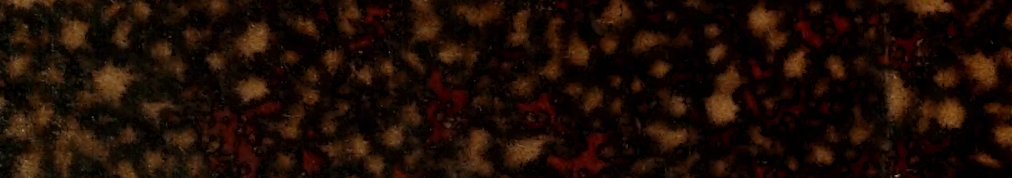

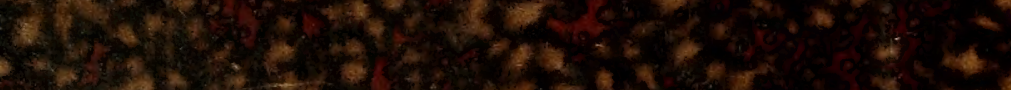

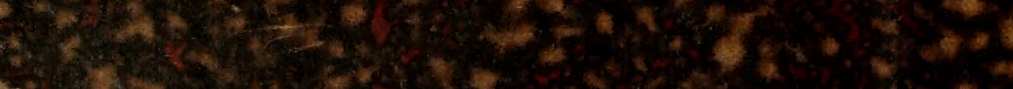

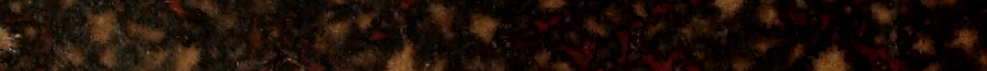

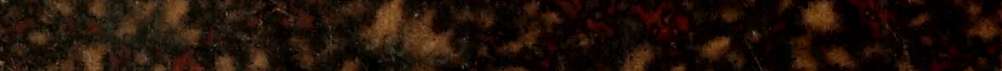

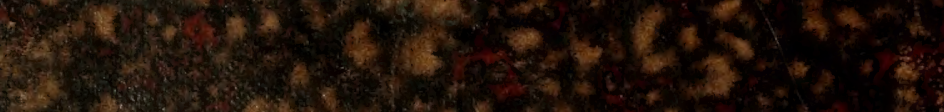

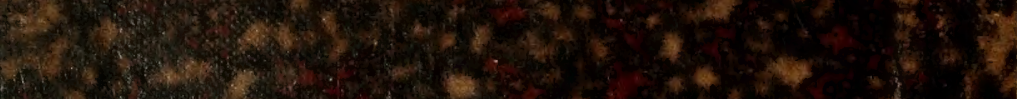

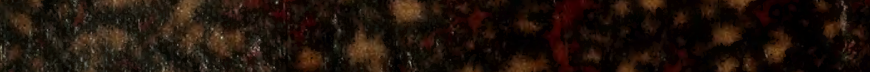

